\title{
PENGARUH RETURN ON EQUITY (ROE), INVESTMENT OPPORTUNITY SET (IOS), DEBT TO EQUITY RATIO (DER), DAN DIVIDEND PAYOUT RATIO (DPR) TERHADAP NILAI PERUSAHAAN PADA PERUSAHAAN MANUFAKTUR DI BURSA EFEK INDONESIA PERIODE 2014-2017
}

\author{
Lidya Anggraeni \\ Fakultas Ekonomi dan Bisnis Islam UIN STS Jambi \\ lidyaanggraeni@uinjambi.ac.id
}

\section{Ringkasan}

Penelitian ini bertujuan untuk mengetahui pengaruh ROE, IOS, DER dan DPR terhadap nilai perusahaan pada industri manufaktur yang terdaftar di Bursa Efek Indonesia (BEI) tahun 2014-2017 secara parsial dan simultan. Populasi dalam penelitian ini adalah perusahaan manufaktur yang terdaftar di Bursa Efek Indonesia (BEI) tahun 2014-2017, sampel penelitian sebanyak 13 perusahaan manufaktur yang diperoleh dengan teknik purposive sampling. Teknik pengumpulan data yang digunakan adalah dokumentasi. Analisis data dilakukan dengan teknik analisis regresi berganda. Hasil penelitian menunjukan bahwa secara simultan variabel ROE, IOE, DER dan DPR berpengaruh bersama-bersama terhadap nilai perusahaan dan secara parsial hanya variabel IOS dan DER yang berpengaruh positif terhadap niali perusahaan, ROE, dan DPR berpengaruh negatif terhadap nilai perusahaan.

Kata Kunci: Return On Equity (ROE), Investment Opportunity Set (IOS), Debt Equity Ratio (DER), Dividend Payout Ratio (DPR), Nilai Perusahaan

\section{PENDAHULUAN}

Setiap perusahaan dalam menjalankan aktivitas pengelolaan usaha selalu mempunyai tujuan yang ingin diraih, baik tujuan jangka pendek maupun tujuan jangka panjang. Tujuan jangka pendek adalah bagaimana perusahaan tersebut dapat mendapatkan laba, serta bagaimana dana yang di investasikan perusahaan tersebut dapat kembali dalam waktu yang singkat. Tujuan jangka panjang yang ingin dicapai yakni bagaimana strategi untuk mempertahankan kelangsungan hidup perusahaan dan memaksimalkan nilai perusahaan. Dalam mencapai tujuannya setiap perusahaan harus memiliki keunggulan kompetitif jika ingin bersaing dengan perusahaan lainnya.

Fama dan French (1998) berpendapat bahwa optimalisasi nilai perusahaan dapat dicapai melalui pelaksanaan fungsi manajemen keuangan, dimana satu keputusan keuangan yang diambil akan mempengaruhi keputusan keuangan lainnya dan berdampak pada nilai perusahaan. Manajemen keuangan menyangkut penyelesaian atas keputusan penting yang diambil perusahaan, antara lain keputusan investasi, keputusan pendanaan, dan kebijakan dividen. Suatu kombinasi yang optimal atas ketiganya akan memaksimumkan nilai perusahaan 
yang selanjutnya akan meningkatkan kemakmuran kekayaan pemegang saham. (Hasnawati,2005).

Salah satu indikator kinerja yang dilakukan oleh manajemen perusahaan dalam mengelola kekayaan yang menunjukkan seberapa besar laba yang diperoleh adalah profitabilitas perusahaan, hal ini karena profitabilitas merupakan bagian penentu nilai perusahaan. Laba yang dihasilkan perusahaan berasal dari penjualan dan keputusan investasi yang dilakukan perusahaan. Salah satu ukuran kinerja perusahaan yang sering digunakan sebagai dasar pengambilan keputusan adalah laba yang dihasilkan oleh perusahaan. Profitabilitas yang tinggi menunjukkan prospek perusahaan yang bagus sehingga investor akan merespon positif dan nilai perusahaan akan meningkat (Sujoko dan Soebiantoro, 2007).

Investasi merupakan tindakan untuk menanamkan sebuah modal yang dimiliki oleh perusahaan pada saat ini dalam bentuk aktiva tetap maupun aktiva lancar yang diharapkan dapat memberikan laba untuk masa yang akan mendatang (Salim dan Moeljadi, 2001:110). Investasi yang dilakukan oleh perusahaan dapat menjadi suatu peluang perusahaan untuk berkembang. Keputusan yang menyangkut investasi akan menentukan sumber dan bentuk dana untuk pembiayaannya. Masalah yang harus dijawab dalam keputusan pendanaan yang dihubungkan dengan sumber dana adalah apakah sumber internal atau eksternal, besarnya hutang dan modal sendiri, dan bagaimana tipe hutang dan modal yang akan digunakan, mengingat struktur pembiayaan akan menentukan cost of capital yang akan menjadi dasar penentuan required return yang diinginkan (Hasnawati, 2005). Investment Opportunity Set (IOS) merupakan keputusan investasi dalam bentuk kombinasi dari aktiva yang dimiliki (asset in place) dan opsi investasi dimasa mendatang dimana IOS dapat mempengaruhi nilai suatu perusahaan (Pagalung, 2003).

Berdasarkan data dari IDX Investment Opportunity Set perusahaan manufaktur selama periode 2014-2017 mengalami fluktuasi, dimana pada tahun 2014 nilai rata-rata IOS 7,93, tahun 2015 mengalami penurunan rata-rata IOS sebesar 4,90 atau sebesar $(38,19) \%$, tahun 2016 rata-rata IOS mengalami kenaikan sebesar 5,23 atau 6,74\% dan pada tahun 2017 rata-rata IOS mengalami kenaikan kembali sebesar 5,34 atau 1,98\%.

Investment Opportunity Set dapat memberikan petunjuk dalam menentukan nilai suatu perusahaan sebagai tujuan utama tergantung dari pengeluaran perusahaan dimasa mendatang (Hasnawati, 2005). Pengukuran Investment Opportunity Set (IOS) sangat beragam, baik menggunakan faktor tunggal maupun kombinasi beberapa faktor, akan tetapi sebagian besar 
menggunakan ukuran data pasar modal dalam menghitung Investment Opportunity Set karena lebih banyak menggunakan ukuran harga saham dan market value of equity sebagai proksi dari Investment Opportunity Set (Hasnawati, 2005).

Oleh karena itu penulis tertarik untuk meneliti, bagaimana perkembangan Return On Equity (ROE), Investement Oppertunity Set (IOS), Debt to Equity Ratio (DER), dan Dividend Payout Ratio (DPR) terhadap nilai perusahaan pada perusahaan Manufaktur di Bursa Efek Indonesia dan bagaimana pengaruh Return On Equity (ROE), Investement Oppertunity Set (IOS), Debt to Equity Ratio (DER), dan Dividend Payout Ratio (DPR) terhadap nilai perusahaan pada perusahaan Manufaktur di Bursa Efek Indonesia secara parsial dan simultan.

\section{METODOLOGI}

Metode penelitian yang dipakai dalam penelitian ini adalah metode deskriptif dengan memberikan gambaran tentang keadaan yang sesungguhnya, kemudian dipergunakan dalam memecahkan permasalahan melalui cara pengumpulan, penyusunan, analisis, lalu diinterpretasikan agar dapat ditarik kesimpulan. Data yang dikumpulkan dalam penelitian ini merupakan data sekunder yang diperoleh dari sumber data seperti jurnal dan sumber lainnya yang tidak langsung diperoleh oleh peneliti atau melalui perantara. Sumber data yang dipakai pada penelitian ini adalah di Bursa Efek Indonesia (BEI) atau Indonesia Stock Exchange (IDX) melalui situs resmi www.idx.co.id

Alat analisis data yang dipakai dalam menjawab permasalahan pertama yaitu memakai alat analisis trend horizontal dan deskriptif kuantitaf menggunakan rumus perkembangan dalam mengukur perkembangan ROE, IOS, DER, dan DPR terhadap nilai perusahaan pada perusahaan manufaktur. Menjawab permasalahan kedua digunakan regresi liner berganda dengan mengadopsi bentuk Tobin's Q yang membandingkan rasio nilai pasar saham perusahaan dengan nilai buku ekuitas perusahaan (Weston dan Copeland, 2001). Persamaan yang terbentuk adalah sebagai berikut :

Tobin' ${ }^{\prime} Q=\alpha+\beta 1 R O E+\beta 2 I O S+\beta 3 D E R+\beta 4 D P R+e$

Dimana :

Tobin's Q : Nilai Perusahaan (Firm Value)

ROE : Profitabilitas

IOS : Keputusan Investasi

DER : Keputusan Pendanaan

DPR : Kebijakan Dividen

$\alpha \quad$ : Konstanta

e : error (kesalahan residu) 
Setelah itu persamaan yang terbentuk diatas akan dilakukan estimasi dengan pengujian statistik melalui Uji $\mathrm{t}$ dan Uji F agar terjawab seberapa besar pengaruhnya secara parsial dan simultan. Kemudian dalam menentukan nilai perusahaan yang merupakan ukuran keberhasilan perusahaan di masa lalu dan di masa datang, dimana nilai perusahaan ini dilihat melalui laporan keuangan perusahaan, seperti tingkat asset dan kewaijiban perusahaan, serta nilai saham yang beredar, seperti tingkat asset dan kewajiban perusahaan, serta nilai saham yang beredar. Salah satu alternatif yang digunakan dalam menilai nilai perusahaan adalah dengan menggunakan Tobin's Q. Tobin's Q ini dikembangkan oleh professor James Tobin (Weston dan Copeland, 2001):

$$
\text { Tobin's } Q=E M V+D E B V+D
$$

Dimana:

EMV : Equity Market Value

EBV : Equity Book Value

D : Nilai buku dari total hutang

\section{HASIL DAN PEMBAHASAN}

Perkembangan Return On Equity (ROE), Investment Opportunity Set (IOS), Debt to Equity Ratio (DER), Dividen Payout Ratio (DPR) dan Nilai Perusahaan

Perkembangan nilai ROE 13 perusahaan manufaktur yang terdaftar di Bursa Efek Indonesia (BEI) periode 2014-2017 menunjukan pertumbuhan yang berfluktuasi. Pada tahun 2014 nilai rata-rata ROE 31,69, tahun 2015 mengalami penurunan rata-rata ROE 21,00 atau sebesar (33,72\%), tahun 2016 rata-rata ROE mengalami kenaikan sebesar 23,99 atau 14,24\% dan pada tahun 2017 rata-rata ROE mengalami penurunan kembali sebesar 22,23 atau (7,36\%).

Perkembangan nilai IOS 13 perusahaan manufaktur yang terdaftar di Bursa Efek Indonesia (BEI) periode 2014-2017 menunjukan pertumbuhan yang berfluktuasi. Pada tahun 2014 nilai rata-rata IOS 7,93, tahun 2015 mengalami penurunan rata-rata IOS sebesar 4,90 atau sebesar $(38,19) \%$, tahun 2016 rata-rata IOS mengalami kenaikan sebesar 5,23 atau 6,74\% dan pada tahun 2017 rata-rata IOS mengalami kenaikan kembali sebesar 5,34 atau 1,98\%.

Perkembangan DER 13 perusahaan manufaktur yang terdaftar di Bursa efek Indonesia (BEI) periode 2014-2017 menunjukan pertumbuhan yang berfluktuasi. Pada tahun 2014 nilai rata-rata DER 0,93, tahun 2015 mengalami penurunan rata-rata DER 0,73 atau sebesar $(21,87 \%)$, tahun 2016 rata-rata DER mengalami penurunan kembali sebesar 0,66 atau $(8,88 \%)$ 
dan pada tahun 2017 rata-rata DER tidak mengalami penurunan ataupun peningkatan yaitu sebesar 0,67 atau $1,05 \%$.

Perkembangan DPR 13 perusahaan manufaktur yang terdaftar di Bursa Efek Indonesia (BEI) periode 2014-2017 menunjukan pertumbuhan yang berfluktuasi. Pada tahun 2014 nilai rata-rata DPR 38,34, tahun 2015 mengalami kenaikan rata-rata DPR 54,11 atau sebesar 41,12\%, tahun 2016 rata-rata DPR mengalami kenaikan kembali sebesar 86,12 atau 54,17\% dan pada tahun 2017 rata-rata DPR mengalami penurunan sebesar 82,48 atau (4,24\%).

Perkembangan nilai Tobin's $Q 13$ perusahaan manufaktur yang terdaftar di Bursa Efek Indonesia (BEI) periode 2014-2017 menunjukan pertumbuhan yang berfluktuasi. Pada tahun 2014 nilai rata-rata tobin's q 3,76, tahun 2015 rata-rata tobin's q mengalami penurunan sebesar 3,18 atau sebesar (14,72\%), tahun 2016 rata-rata tobin's q mengalami kenaikan sebesar 3,19 atau $0,42 \%$ dan pada tahun 2017 rata-rata tobin's q mengalami kenaikan kembali sebesar 3,56 atau $11,58 \%$.

Hasil Analisis Regresi Return On Equity (ROE), Investment Opportunity Set (IOS), Debt to Equity Ratio (DER), Dividen Payout Ratio (DPR) dan Nilai Perusahaan

Analisis statistik dalam penelitian ini menggunakan analisis regresi linier berganda. Dari hasil perhitungan dengan menggunakan bantuan SPSS didapatkan hasil seperti pada tabel 1 sebagai berikut:

Tabel 1 Hasil Analisis Regresi

\begin{tabular}{|c|c|c|c|c|c|c|}
\hline \multirow{2}{*}{\multicolumn{2}{|c|}{ Model }} & Unstanda & coefficient & \multirow{2}{*}{$\begin{array}{l}\begin{array}{l}\text { Standardize } \\
\text { d }\end{array} \\
\text { Coefficient } \\
\frac{\text { Beta }}{}\end{array}$} & \multirow[t]{2}{*}{$\mathrm{t}$} & \multirow[t]{2}{*}{ Sig. } \\
\hline & & B & Std. Error & & & \\
\hline 1 & (Constant) & 2,832 &, 375 & & 7,559 &, 000 \\
\hline & ROE &,- 033 & ,020 &,- 276 & $-1,683$ & ,099 \\
\hline & IOS & ,568 & ,067 & 1,414 & 8,518 &, 000 \\
\hline & DER & $-2,724$ & ,465 &,- 383 & $-5,851$ & , 000 \\
\hline & DPR &, 002 & ,002 & ,036 &, 746 & ,460 \\
\hline
\end{tabular}

Sumber : Output SPSS (data diolah)

Dari hasil regresi linier berganda pada tabel 1 diatas maka dapat diperoleh persamaan sebagai berikut:

$\mathrm{Y}=2,832-0,033 \mathrm{ROE}+0,568 \mathrm{IOS}-2,724 \mathrm{DER}+0,002 \mathrm{DPR}$

Hasil analisis regresi dapat dijelaskan bahwa apabila Variabel ROE, IOS, DER, dan DPR dalam keadaan tetap maka nilai perusahaan adalah sebesar 2,832 persen dengan asumsi 
variabel lain dianggap tetap, selanjutnya apabila Return On Equity mengalami kenaikan sebesar 1 persen maka nilai perusahaan akan mengalami penurunan sebesar $-0,033$. Nilai koefisien regresi $-0,033$ berarti meningkatnya variabel ROE akan menurunkan variasi Nilai Perusahaan. Investment Opportunity Set sebesar 0,568 artinya apabila Investment Opportunity Set mengalami kenaikan sebesar 1 sedangkan variabel lain dianggap konstan, maka Nilai Perusahaan mengalami kenaikan sebesar 0,568. Nilai koefisien regresi 0,568 berarti meningkatnya veriabel IOS akan meningkatkan variasi Nilai Perusahaan.

Debt to Equity Ratio sebesar -2,724 artinya apabila DER mengalami kenaikan sebesar 1 sedangkan variabel lain dianggap konstan, maka Nilai Perusahaan mengalami penurunan sebesar -2,724 dengan asumsi variabel lain dianggap tetap. Nilai koefisien regresi -2,724 berarti meningkatnya variabel DER akan menurunkan variasi Nilai Perusahaan. Dividend Payout Ratio sebesar 0,002 artinya apabila DPR mengalami kenaikan 1 sedangkan variabel lain dianggap konstan, maka Nilai Perusahaan mengalami kenaikan sebesar 0,002, dengan asumsi variabel lain dianggap tetap. Nilai koefisien regresi 0,002 berarti meningkatnya variabel DPR akan meningkatkan variasi Nilai Perusahaan.

Hasil pengujian secara simultan (Uji F) didapatkan nilai Sig $0,005^{\text {b }}$ ini menunjukkan bahwa nilai signifikansi lebih kecil dengan tingkat keyakinan 95\% ( $\alpha=5 \%)$ maka dapat dijelaskan bahwa seluruh variabel bebas (ROE, IOS, DER dan DPR) secara serentak atau secara bersamaan akan memiliki pengaruh terhadap variabel terikat. uji signifikansi untuk pengaruh ROE, IOS, DER dan DPR secara bersama-sama terhadap Nilai Perusahaan (uji statistik F) adalah $0,000<0,05$ dan menghasilkan nilai $\mathrm{F}$ hitung sebesar 98,778 $>\mathrm{F}$ tabel 2.57. Nilai $F$ tabel pada taraf signifikansi 0,05 adalah $=F(k ; n-k)=F(4 ; 48)=2,57$. Hasil analisis dalam penelitian ini menunjukkan bahwa secara umum Nilai Perusahaan dapat dijelaskan dengan Return on Equity (ROE), Investment Opportunity Set (IOS), Debt to Equity Ratio (DER) dan Dividend Payout Ratio (DPR). Maka dapat disimpulkan bahwa variabel independen dalam penelitian ini secara bersama-sama (simultan) berpengaruh terhadap variabel dependen yaitu Nilai Perusahaan.

Sementara itu untuk mengukur signifikansi pengaruh Return on Equity, Investment Opportunity Set, Debt to Equity Ratio dan Dividend Payout Ratio terhadap Nilai Perusahaan pada perusahaan Manufaktur di BEI periode 2014-2017 secara parsial dapat menggunakan analisis varians (anova) dengan menggunakan uji statistik t. Hasil uji secara parsial (uji-t) variabel Return On Equity (ROE) menunjukkan nilai t hitung $<\mathrm{t}$ tabel $(-1.683<2.011)$ dan 
nilai signifikansi di bawah $0,025(0.099>0.025)$ yang berarti tidak terdapat pengaruh signifikan antara variabel Return On Equity (ROE) terhadap Nilai Perusahaan sehingga H1 ditolak. Hasil Penelitian ini mendukung dengan penelitian terdahulu yang dilakukan sulastri dan dkk (2017), menyatakan bahwa secara parsial variabel ROE tidak berpengaruh terhadap Nilai Perusahaan.

Hasil uji secara parsial (uji-t) variabel Investment Oppertunity Set (IOS) menunjukkan nilai t hitung $<\mathrm{t}$ tabel $8,518>2.055)$ dan nilai signifikansi di bawah $0,05(0.000<0.025)$ yang berarti terdapat pengaruh positif dan signifikan secara parsial antara variabel Investment Oppertunity Set (IOS) terhadap Nilai Perusahaan, sehingga H2 diterima. Hasil penelitian ini mendukung penelitian yang telah dilakukan Syardiana dan dkk (2015) yang menyatakan terdapat pengaruh yang signifikan positif antara perubahan Inveatment Oppertunity Set (IOS) terhadap Nilai Perusahaan. Hasil uji secara parsial (uji-t) variabel Debt to Equity Ratio menunjukkan nilai $\mathrm{t}$ hitung $<\mathrm{t}$ tabel $(-5,851<2.055)$ dan nilai signifikansi $0.000<0.025$ yang berarti terdapat pengaruh negatif dan signifikan secara parsial antara variabel Debt to Equity Ratio (DER) terhadap Nilai Perusahaan, sehingga H3 diterima. Hasil penelitian ini mendukung penelitian dilakukan oleh Afzal dan dkk (2012) yang menyatakan terdapat pengaruh yang signifikan positif antara perubahan Debt to Equity Ratio (DER) terhadap Nilai Perusahaan. Hasil uji secara parsial (uji-t) variabel Dividend Payout Ratio menunjukkan nilai t hitung $<\mathrm{t}$ tabel $(0,746<2.055)$ dan nilai signifikansi $0.460>0.025$ yang berarti secara parsial tidak memiliki pengaruh signifikan antara variabel Dividend Payout Ratio (DPR) terhadap Nilai Perusahaan. Sehingga H4 ditolak. Hasil uji t variabel Dividend Payout Ratio (DPR) ini sesuai dengan penelitian yang dilakuan oleh Suroto (2015) yang menyatakan bahwa Dividend Payout Ratio (DPR) tidak memiliki pengaruh signifikan terhadap Nilai Perusahaan.

Tabel.2. Koefisien Determinasi (secara simultan) Model Summary ${ }^{\mathrm{b}}$

\begin{tabular}{|c|c|c|c|}
\hline Model & R & R Square & Adjusted R Square \\
\hline 1 &, $945^{\text {a }}$ &, 894 &, 885 \\
\hline
\end{tabular}

Sumber : Output SPSS (data diolah)

Hasil dari nilai adjusted R-Square dari regresi digunakan untuk mengetahui besarnya Nilai Perusahaan yang dipengaruhi oleh variabel-variabel bebasnya yaitu Return on Equity, Investment Opportunity Set, Debt to Equity Ratio dan Dividend Payout Ratio. Pada tabel 2 menunjukkan bahwa koefisien determinasi yang menunjukkan dari nilai adjusted R-Square sebesar 0,894. Hal ini berarti bahwa 89,4\% variabel dependen yaitu Nilai Perusahaan dapat 
dijelaskan oleh empat variabel dependen yaitu Return on Equity (ROE), Investment Opportunity Set (IOS), Debt to Equity Ratio (DER) dan Dividend Payout Ratio (DPR) sedangkan sisanya sebesar 10,6\% Nilai Perusahaan dijelaskan oleh variabel lain yang tidak di teliti pada penelitian ini.

Sedangkan untuk mengetahui besarnya pengaruh Return on Equity (ROE), Investment Opportunity Set (IOS), Debt to Equity Ratio (DER) dan Dividend Payout Ratio (DPR) secara parsial dapat dilakukan dengan koefisien determinasi dengan symbol $\mathrm{r}^{2}$, dimana koefisien ini dapat diperoleh dengan mengkuadratkan koefisien korelasi dengan symbol $r^{2}$ yang dapat dilihat pada tabel berikut ini:

Tabel.3. Koefisien Determinasi (secara parsial)

Coefficients $^{\mathrm{a}}$

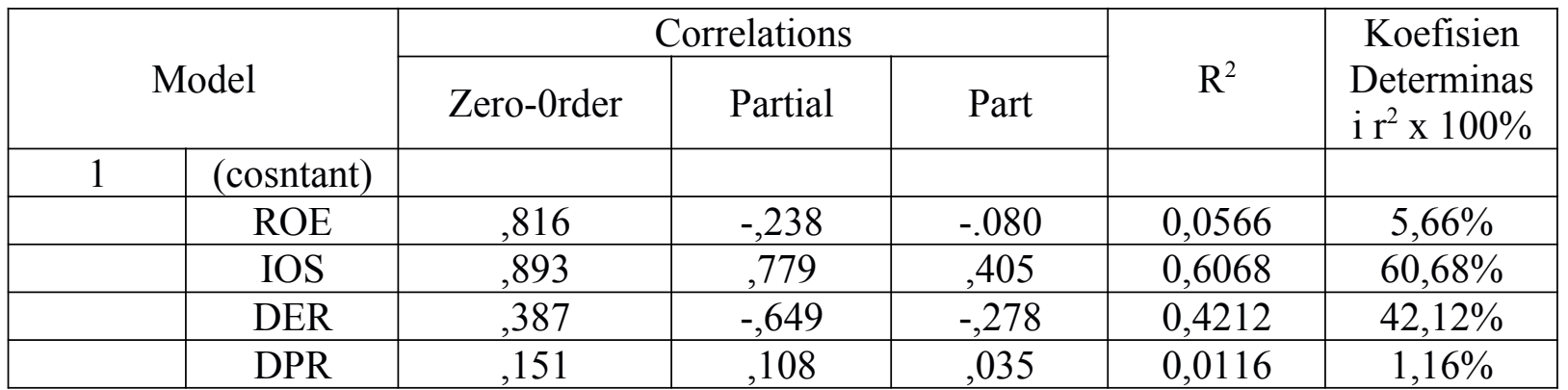

Sumber : Output SPSS (data diolah)

Berdasarkan tabel 3 diatas, diketahui besarnya pengaruh Return on Equity adalah sebasar 0,0566 atau 5,66\%, besarnya pengaruh Investment Opportunity Set sebesar 0,6068 atau 60,68\% sedangkan besarnya pengaruh Debt to Equity Ratio adalah sebesar 0,4212 atau 42,12\% dan besarnya pengaruh Dividend Payout Ratio adalah sebesar 0,0116 atau 1,16\%. Berdasarkan hasil koefisien determinasi parsial $\left(\mathrm{r}^{2}\right)$ pada tabel 3diketahui besarnya pengaruh dari keempat variabel yang diteliti yang mempunyai pengaruh terbesar adalah Investment Opportunity Set sebesar 0,6068 atau 60,68\% sehingga dapat disimpulkan bahwa IOS mempunyai pengaruh paling dominan terhadap Nilai Perusahaan dibandingkan dengan variabel lain.

Tidak semua variabel yang diteliti berpengaruh signifikan terhadap Nilai Perusahaan. Pengujian secara parsial (uji t) menunjukkan hanya variabel Investment Opportunity Set dan Debt to Equity Ratio yang memiliki pengaruh yang signifikan sedangkan variabel Return On Equity dan Dividend Payout Ratio tidak berpengaruh signifikan terhadap Nilai Perusahaan. ROE menghasilkan nilai $\mathrm{t}$ hitung $<\mathrm{t}$ tabel $(-1,683<2.011)$ dan nilai signifikansi $0.099>0.025$ yang berarti secara parsial tidak memiliki pengaruh signifikan antara variabel Return on Equity (ROE) terhadap Nilai Perusahaan. Meskipun ROE menunjukan kemampuan perusahaan untuk 
menghasilkan laba bersih mengalami penurunan, investor tetap melakukan investasi pada perusahaan tersebut. Sayekti dan Wondabio (2011) dalam Cheng dan Christiawan (2007) menyatakan bahwa informasi mengenai laba digunakan oleh investor, tetapi kegunaan informasi laba tersebut bagi investor sangat terbatas sehingga investor juga mempertimbangkan informasi lainnya.

Pengujian secara parsial, IOS menunjukkan nilai $t$ hitung $>t$ tabel $(8.518>2.011)$ dan nilai signifikansi di bawah $0,025(0.000<0.025)$ yang berarti terdapat pengaruh signifikan antara variabel Investment Opportunity Set (IOS) terhadap Nilai Perusahaan maka hipotesis yang diajukan diterima. Hasil penelitian ini mendukung Gita Syardiana dan dkk (2015) yang menyatakan terdapat pengaruh yang signifikan positif antara perubahan Investment Oppertunity Set (IOS) terhadap Nilai Perusahaan. DER menghasilkan nilai $\mathrm{t}$ hitung $<\mathrm{t}$ tabel ($5,851<2.011)$ dan nilai signifikansi di bawah $0,025(0.000<0.025)$ yang berarti terdapat pengaruh signifikan antara variabel Debt to Equity Ratio (DER) terhadap Nilai Perusahaan. Hasil penelitian ini mendukung penelitian dilakukan oleh Afzal dan dkk (2012) yang menyatakan terdapat pengaruh yang signifikan positif antara perubahan Debt to Equity Ratio (DER) terhadap Nilai Perusahaan. Keputusan struktur modal yang efektif dapat merendahkan biaya modal yang dikeluarakan oleh suatu perusahaan.

Keuntungan perusahaan mengunakan hutang yaitu bunga yang dibayarkan dapat dipotong untuk tujuan pajak, sehingga menurunkan biaya efektif dari hutang (setiana dan Rahayu, 2012). Dengan adanya perencanaan yang matang menentukan struktur modal, diharapkan perusahaan dapat meningkatkan nilai perusahaan dan lebih unggul dalam menghadapi persaingan bisnis (Bukit, 2012). Hal ini sesuai teori keputusan pendanaan, dikatakan jika menejer memiliki keyakinan bahwa prospek perusahaan baik, dan karenanya ingin agar harga saham yang meningkat, tentu manajer ingin mengkomunikasikan hal tersebut kepada investor. Manajer bisa mengunkan hutang yang lebih banyak, nantinya berperan sebagai sinyal yang lebih terpercaya. Karena perusahaan yang meningkatkan hutang bisa dipandang sebagai perusahaan yang yakin akan prospek di masa yang akan datang.

DPR menghasilkan nilai $t$ hitung $<\mathrm{t}$ tabel $(0,746<2.011)$ dan nilai signifikansi $0.460>$ 0.025 yang berarti secara parsial tidak memiliki pengaruh signifikan antara variabel Dividend payout Ratio (DPR) terhadap Nilai Perusahan. Hasil uji t variabel Dividend Payout Ratio (DPR) ini sesuai dengan penelitian yang dilakuan oleh Suroto (2015) yang menyatakan bahwa Dividend Payout Ratio (DPR) tidak memiliki pengaruh signifikan terhadap Nilai Perusahaan, 
akan tetapi bertolak belakang dengan penelitian yang dilakukan oleh Hari Purnama (2016) yang menyatakan bahwa Dividend Payout Ratio berpengaruh secara parsial terhadap Nilai Perusahaan.

\section{KESIMPULAN DAN SARAN}

\section{Kesimpulan}

Berdasarkan hasil penelitian pengaruh Return on Equity, Investment Opportunity Set, Debt to Equity Ratio dan Dividend Payout Ratio terhadap Nilai Perusahaan pada perusahaan Manufaktur di BEI periode 2014-2017 dengan menggunakan regreai linier berganda menyimpulkan bahwa : Return On Equity secara parsial tidak berpengaruh terhadap Nilai Perusahaan. Hal tersebut dibuktikan dengan nilai t hitung $<\mathrm{t}$ tabel $-1.683<2.011$ dan nilai signifikansi di atas 0,025 $(0.099>0.025)$ yang berarti tidak terdapat pengaruh signifikan antara variabel Return On Equity (ROE) terhadap Nilai Perusahaan. Investment Opportunity Set menunjukkan nilai $\mathrm{t}$ hitung $<\mathrm{t}$ tabel $8,518>2.055)$ dan nilai signifikansi di bawah 0,025 $(0.000<0.025)$ yang berarti terdapat pengaruh positif dan signifikan secara parsial antara variabel Inveatment Oppertunity Set (IOS) terhadap Nilai Perusahaan. Debt to Equity Ratio menunjukkan nilai $\mathrm{t}$ hitung $<\mathrm{t}$ tabel $(-5,851<2.055)$ dan nilai signifikansi $0.000<0.025$ yang berarti terdapat pengaruh positif dan signifikan secara parsial antara variabel Debt to Equity Ratio (DER) terhadap Nilai Perusahaan, sedangkan variabel Dividend Payout Ratio menunjukkan nilai $\mathrm{t}$ hitung $<\mathrm{t}$ tabel $(0,746<2.055)$ dan nilai signifikansi $0.460>0.025$ yang berarti secara parsial tidak memiliki pengaruh signifikan antara variabel Dividend Payout Ratio (DPR) terhadap Nilai Perusahaan. Berarti hanya variabel IOS dan DER yang di teliti memiliki pengaruh yang signifikan terhadap Nilai Perusahaan pada pada perusahaan Manufaktur di BEI periode 2014-2017.

Besarnya pengaruh Return on Equity, Investment Opportunity Set, Debt to Equity Ratio dan Dividend Payout Ratio terhadap Nilai Perusahaan secara simultan diperoleh nilai adjusted R-Square sebesar 0,885 hal ini menunjukkan bahwa ketiga variabel bebas yaitu ROE, IOS, DER, dan DPR secara simultan berpengaruh sebesar 88,5\% terhadap Nilai Perusahaan. Melalui hasil perhitungan koefisien determinasi determinasi (r2) dari keempat variabel yang diteliti yang mempunyai pengaruh terbesar adalah Investment Opportunity Set sebesar 0,6068 atau 60,68\% sehingga dapat disimpulkan bahwa IOS mempunyai pengaruh paling dominan terhadap Nilai Perusahaan dibandingkan dengan variabel lainnya.

\section{DAFTAR PUSTAKA}


Analisa, Yangs. (2011). Pengaruh Ukuran Perusahaan, Leverage, Profitabilitas Dan Kebijakan Dividen Terhadap Nilai Perusahaan (Studi Pada Perusahaan Manufaktur Yang Terdaftar Di Bursa Efek Indonesia Tahun 2006-2008). Skripsi. Semarang: UNDIP.

Ang, Robert. (1997). Buku Pintar Pasar Modal Indonesia. Jakarta: Media Staff Indonesia.

Brigham F. Eugene \& Joel, F. Houston. (1998). Fundamentals of Financial Management. Eighth Edition. New York: The Dryden Press. Harcourt Brace College Publishers.

Brigham F. Eugene \& Joel, F. Houston. (2001). Manajemen Keuangan II. Jakarta: Salemba Empat.

Brigham F. Eugene \& Joel, F. Houston. (2006). Dasar-Dasar Manajemen Keuangan. Diterjemahkan oleh: Ali Akbar Yulianto. Jakarta: PT. Salemba Empat.

Brigham F. Eugene \& Joel, F. Houston. (2011). Dasar-dasar Manajemen Keuangan (buku 2). Diterjemahkan oleh: Ali Akbar Yulianto. Jakarta: Salemba Empat. Damodaran, A Swath. (2001). Corporate Finance: Theory and Practice 2nd ed. USA: John Wiley and Sons Inc.

Fenandar, Gany Ibrahim. (2012). "Pengaruh Keputusan Investasi, Keputusan Pendanaan dan Kebijakan Dividen Terhadap Nilai Perusahaan”. Skripsi. Semarang: Universitas Diponegoro.

Fitriana, Pingkan Mayosi. (2014). "Pengaruh Keputusan Investasi, Keputusan Pendanaan, dan Profitabilitas Terhadap Nilai Perusahaan: Kebijakan Dividen Sebagai Variabel Intervening”. Skripsi. Semarang: Universitas Diponegoro. 